Tropical Journal of Pharmaceutical Research May 2019; 18 (5): 1057-1060

ISSN: $1596-5996$ (print); 1596-9827 (electronic)

(c) Pharmacotherapy Group, Faculty of Pharmacy, University of Benin, Benin City, 300001 Nigeria.

Original Research Article

http://dx.doi.org/10.4314/tjpr.v18i5.20

\title{
Effect of Taoren-Quyu decoction on endometriosis in rats
}

\author{
Ye Jin, Jian-hua Zheng* \\ Department of Gynecology and Obstetrics, Women's Hospital School of Medicine Zhengjiang University, Hangzhou, 310006, \\ Zhejiang Province, China
}

*For correspondence: Email: zhengjianhua0451@126.com; Tel: +86-0451-85556024

Sent for review: 26 June 2017

Revised accepted: 5 May 2019

\begin{abstract}
Purpose: To study the effect of traditional Chinese Medicine formula Taoren-Quyu decoction (TQD) on endometriosis.

Method: Fifty female Wistar rats were randomly separated into five groups (10 rats/group): normal control, model (untreated) group, positive control (danazol), $200 \mathrm{mg} / \mathrm{kg} /$ day (low dose) or $400 \mathrm{mg} / \mathrm{kg} /$ day (high dose). All rats were prepared into endometriosis except for normal control rats. TDQ groups rats were orally administered of TQD for 5 weeks. After treatment, the rats were sacrificed by cervical dislocation. The number of total endometriotic lesions were counted. Serum levels of cancer antigen 125 (CA-125), interleukin 13 (IL-13), interleukin 18 (IL-18) and peritoneal fluid tumor necrosis factoralpha (TNF- $\alpha$ ) were measured by ELISA kits.

Result: Compared with control rats, TQD reduced the number of total endometriotic lesions significantly (12.7 $\pm 1.2, p<0.01)$, as well as serum levels of CA-125 (6.4 $\pm 1.2 \mathrm{U} / \mathrm{mL}), \mathrm{IL}-18(118.6 \pm 7.4 \mathrm{pg} / \mathrm{mL}), \mathrm{LL}-$ $13(6.3 \pm 0.8 \mathrm{pg} / \mathrm{mL})$ and peritoneal fluid TNF- $\alpha(231.5 \pm 11.7 \mathrm{pg} / \mathrm{mL})(p<0.01)$.

Conclusion: The results reveal that TQD exerts anti-endometriotic effect in rats by inhibiting inflammatory factors. Therefore, TQD has potentials for use in the treatment of endometriosis.
\end{abstract}

Keywords: Taoren-Quyu decoction, Endometriosis, Cancer antigen, Endometriotic lesions, Matrix metalloproteinase

This is an Open Access article that uses a fund-ing model which does not charge readers or their institutions for access and distributed under the terms of the Creative Commons Attribution License (http://creativecommons.org/licenses/by/4.0) and the Budapest Open Access Initiative (http://www.budapestopenaccessinitiative.org/read), which permit unrestricted use, distribution, and reproduction in any medium, provided the original work is properly credited.

Tropical Journal of Pharmaceutical Research is indexed by Science Citation Index (SciSearch), Scopus, International Pharmaceutical Abstract, Chemical Abstracts, Embase, Index Copernicus, EBSCO, African Index Medicus, JournalSeek, Journal Citation Reports/Science Edition, Directory of Open Access Journals (DOAJ), African Journal Online, Bioline International, Open-J-Gate and Pharmacy Abstracts

\section{INTRODUCTION}

As a common gynaecological disease, endometriosis usually induces dysmenorrhoea, chronic pelvic pain and infertility. The morbidity of endometriosis is $14 \%$ in normal population and $40 \%$ in infertile women [1]. The typical symptoms of endometriosis is ectopic implantation and growth of endometrial tissue and local sterile inflammation of peritoneal cavity. Proliferation, adhesion, and migration of ectopic endometrial tissue are required to establish endometriotic lesions in the peritoneal cavity $[2,3]$.

The endometriosis-associated inflammatory response, tissue repair and neo-vascularization are dependent on the peritoneal fluids macrophages and their secretary products/ cytokines [4]. These cytokines may play major roles in regulating cell proliferation, activation, motility, adhesion, chemotaxis and morphogenesis in the pathogenesis of endometriosis [5]. Increased peritoneal fluids 
concentration of cytokines that lead to the migration, proliferation, and activation of macrophages have been reported in patients with endometriosis. The biomarkers such as cancer antigen 125 (CA-125) and IL-13, IL-18 and TNF-alpha levels in the peritoneal fluids were found linked with endometriosis [6]. Although surgical and hormonal treatments are applied as the common interventions, the unpleasant side effects limited the use of these interventions. Some medicinal plants were shown to be potential treatment for the disease [7]. Taoren-Quyu Decoction (TQD), which is composed of Prunus persica (L.) Batsch 10 gram, Salvia miltiorrhiza Bge. Ten grams Angelica sinensis 5 gram and Leonurus artemisia (Laur.) S. Y. Hu F 5 gram, is a famous traditional Chinese Medcine formula in China. TQD has been used to treat endometriosis for many years and has achieved good curative action. In this study, the anti-endometriotic effect of TaorenQuyu Decoction (TQD) was investigated in human endometriotic cells and rats.

\section{EXPERIMENTAL}

\section{Preparation of TQD}

The medicinal herbs of TQD were collected from Zhunyi City, Guizhou Province in China in May 2017. Taxonomic identification of the plants was performed by Prof Lin $\mathrm{Hu}$ of Harbin Medical University China. A voucher specimen (no. TQD 20170505) was deposited in the herbarium of College of Pharmacy, Harbin Medical University, China for future reference. Prunus persica (L.) Batsch 10 gram, Salvia miltiorrhiza Bge. 10 gram, Angelica sinensis 5 gram and Leonurus artemisia (Laur.) S. Y. Hu F 5 gram were mixed and decocted with ten times of volume of water for 40 minutes. It was repeated for twice. Then the decoction was filtrated and concentrated into the volume of $100 \mathrm{~mL}$ to obtain TQD [8].

\section{Animals and grouping}

Female Wistar rats weighing 200 - $220 \mathrm{~g}$ were obtained from Experimental animal center of Heilongjiang Province, Heilongjiang, China. The animals had free access to feed and water, and were allowed to acclimatize for at least one week before use. All animal experiments were approved by the Animal Care and Use Committee of Harbin Medical University (approval ref no. 20131007) and were carried out in compliance with the Animal Welfare Act and $\mathrm{NIH}$ guidelines (NIH publication no. 80-23, revised 1996) [9]. Endometriosis was induced in rats using a previously established method with modifications [10]. The uterine horns of the donor mice were removed and put into a dish containing PBS. The endometrium-rich fragments $(1 \mathrm{~cm})$ from the middle-third of the uterine horn were finely and uniformly chopped. The fragments ( 20 pieces) suspended in PBS were injected into the peritoneal cavity of recipient mice with a micropipette to induce the formation of endometriosis-like lesions. Forty (40) rats with induced endometriosis were randomly divided into four groups (10 rats/group): control, Danazol ${ }^{\circledR}$, high-dose TQD and low-dose TQD. Ten normal rats were used as normal control. Rats were orally administered either vehicle (normal control, $200 \mu \mathrm{L}$ of phosphate buffered saline) alone or TQD 200 $\mathrm{mg} / \mathrm{kg} /$ day (low dose) or $400 \mathrm{mg} / \mathrm{kg} /$ day (high dose) for 5 weeks. Danazol was used as positive control (reference). Danazol produces an environment with high androgen and low estrogen levels, which leads to the atrophy of endometriotic implants [11]. After induction of endometriosis for 4 weeks, the rats were sacrificed by cervical dislocation and the peritoneum and visceral organs were examined visually to measure the number of endometriotic lesions $(1>\mathrm{mm})$.

\section{Enzyme linked immunosorbent assay}

After all the treatment was finished, the rats were sacrificed and the samples of peritoneal fluids and serum were taken. The peritoneal fluid samples of the rats were centrifuged at 12,000 rpm for $10 \mathrm{~min}$ at $4{ }^{\circ} \mathrm{C}$. Then, the supernatants were collected, aliquoted, and stored frozen at $-80{ }^{\circ} \mathrm{C}$ until used for further evaluation. The serum CA-125 levels, and the levels of IL-13, IL18 and TNF- $\alpha$ of the peritoneal fluids were detected using ELISA as directed by the manufacturer (RUIQI Bio Co. Ltd, Shanghai, China).

\section{Statistical analysis}

Data was expressed by means $\pm S D$, GraphPad Prism version 5 (GraphPad, San Diego, CA, USA) was used. Statistical comparison between two groups was made using Student's $t$-test. For comparing more than two groups, one-way analysis of variance (ANOVA) was used followed by Tukey test with a significance of $p<0.05$. All errors are shown as standard deviation (SD).

\section{RESULTS}

\section{TQD inhibited the formation of endome- triosis-like lesions in rats}

As shown in Table 1, TQD-treated rats had a reduced number of total endometriotic lesions as 
compared with vehicle-treated controls $(p<$ 0.01). Thus, TQD inhibit the formation of endometriosis-like lesions in rats.

Table 1: Effect of TQD on the formation of endometriosis-like lesions in rats $(n=10)$

\begin{tabular}{lc}
\hline Group & No. of lesion/mouse \\
\hline Normal & $11.3 \pm 1.1^{\prime \prime}$ \\
Control & $21.8 \pm 1.5$ \\
Danazol & $16.4 \pm 1.3$ \\
TQD-400 & $12.7 \pm 1.2^{\prime \prime}$ \\
TQD-200 & $14.5 \pm 1.4$ \\
\hline${ }^{\prime} P<0.05, " p<0.01$ compared with control group
\end{tabular}

\section{Effect of TQD on rat biochemical profile}

As shown in Table 2, the serum CA-125 level, and the IL-18 and TNF- $\alpha$ levels of peritoneal fluids in control group rats were higher than those of sham group $(p<0.01)$. The serum CA125 level, and the IL-18 and TNF- $\alpha$ level of peritoneal fluids of high dose of TQD were significantly lower than that of the control group $(p<0.01)$. The IL-13 level of peritoneal fluids in control group was significantly lower than that of sham group $(p<0.01)$. After treated with high dose of TQD, the IL-13 level of peritoneal fluids was significantly higher than that of the control group $(p<0.01)$.

Table 2: Effect of TQD on biochemical profile of rats

\begin{tabular}{|c|c|c|c|c|}
\hline Group & $\begin{array}{l}\text { CA-125 } \\
(\mathrm{U} / \mathrm{mL})\end{array}$ & $\begin{array}{c}\mathrm{IL-13} \\
(\mathrm{pg} / \mathrm{mL})\end{array}$ & $\begin{array}{c}\mathrm{IL-18} \\
(\mathrm{pg} / \mathrm{mL})\end{array}$ & $\begin{array}{c}\text { TNF- } \alpha \\
\text { (pg/mL) }\end{array}$ \\
\hline Normal & $5.9 \pm 0.4$ & $7.6 \pm 1.4$ & $112.4 \pm 9.8$ & $213.4 \pm 15.4$ \\
\hline Control & $12.3 \pm 1.1$ & $2.4 \pm 0.6$ & $321.8 \pm 21.5$ & $874.2 \pm 13.5$ \\
\hline Danazol & $6.2 \pm 1.3^{\mathrm{n}}$ & $6.5 \pm 0.9^{\prime \prime \prime}$ & $124.5 \pm 8.7^{* \pi}$ & $241.6 \pm 14.9$ \\
\hline TQD-H & $6.4 \pm 1.2^{\prime \prime}$ & $6.3 \pm 0.8^{-1}$ & $118.6 \pm 7.4^{\prime \prime}$ & $231.5 \pm 11.7$ \\
\hline TQD-L & $7.8 \pm 2.4$ & $5.1 \pm 0.7$ & $154.2 \pm 11.4$ & $264.1 \pm 12.9^{\prime}$ \\
\hline
\end{tabular}

\section{DISCUSSION}

Endometriosis is usually associated with inflammation of the pelvic area and peritoneum. This hallmark has led to searches of inflammatory markers in the circulation which could potentially predict the presence of endometriosis, and the possibility of a clinically silent systemic inflammatory state in women with endometriosis. These results, which covered three classes of molecules associated with systemic inflammation, namely oxylipins, immunomodulatory proteins and CRP, were largely similar to minimal differences at a level which precludes their use as diagnostic biomarkers for endometriosis. This may explain why there has been no unequivocal consensus on the levels of circulating cytokine in endometriosis $[12,13]$.
In this study, CA125, IL-13, IL-18 and TNF- $\alpha$ were chosen to reflect the effects of TQD on the model rats with endometriosis. Serum CA-125 measurement is now a consolidated method for diagnosing endometriosis, and the serum CA125 values were found significantly elevated in patients with ovarian and mixed endometriosis lesions [14]. The levels of IL-18 in peritoneal fluids were markedly higher in women with peritoneal, minimal-to mild-stage endometriosis than in controls [15]. The level of TNF- $\alpha$ in peritoneal fluid has been demonstrated as a biomarker to discriminate between patients with endometriosis and those without [16]. It was found in the present study that TQD markedly decreased the serum levels of $\mathrm{CA}-125$ and the levels of IL-18 and TNF- $\alpha$ in the peritoneal fluids and significantly increased the levels of IL-13 in the peritoneal fluids.

\section{CONCLUSION}

The findings of this study show that TQD exhibits anti-endometriotic effect in rats by inhibiting inflammatory factors, and is thus a promising therapeutic agent for the treatment of endometriosis.

\section{DECLARATIONS}

\section{Conflict of interest}

No conflict of interest is associated with this work.

\section{Contribution of authors}

We declare that this work was done by the authors named in this article and all liabilities pertaining to claims relating to the content of this article will be borne by the authors. Jian-hua Zheng designed all the experiment and revised the paper. Ye Jin performed the experiment and wrote the paper.

\section{Open Access}

This is an Open Access article that uses a funding model which does not charge readers or their institutions for access and distributed under the terms of the Creative Commons Attribution License (http://creativecommons.org/licenses/by/ 4.0) and the Budapest Open Access Initiative (http://www.budapestopenaccessinitiative.org/rea d), which permit unrestricted use, distribution, and reproduction in any medium, provided the original work is properly credited. 


\section{REFERENCES}

1. Bulun SE. Endometriosis. N Engl J Med 2009; 360: 268279.

2. Van Langendonckt A, Casanas-Roux F, Donnez J. Oxidative stress and peritoneal endometriosis. Fertil Steril 2002; 77: 861-870.

3. Bedaiwy MA, Falcone $T$, Sharma RK, Goldberg JM, Attaran $M$, Nelson DR. Prediction of endometriosis with serum and peritoneal fluid markers: a prospective controlled trial. Hum Reprod 2002; 17: 426-431.

4. Che XH, Park EJ, Zhao YZ, Kim WH. Tanshinone II A induces apoptosis and $S$ phase cell cycle arrest in activated rat hepatic stellate cells. Basic Clin Pharmacol Toxicol 2010; 106: 30-37.

5. Chen X, Zhou ZW, Xue CC, Li XX. Role of P-glycoprotein in restricting the brain penetration of tanshinone IIA, a major active constituent from the root of Salvia miltiorrhiza Bunge, across the blood-brain barrier. Xenobiotica 2007; 37: 635-678.

6. Fassbender A, OveTQDrgh L, Verdrengh E, Kyama CM. How can macroscopically normal peritoneum contribute to the pathogenesis of endometriosis? Fertil Steril 2011; 96: 697-699.

7. TC Zhang, HF Cong, S Zhao, $Q$ Zhang, XM Gu. Jing Tong $Y u$ Shu, a traditional Chinese medicine, suppresses IL-1 $\beta$ and IL-6 gene expressions in macrophages, and alleviates endometriosis. Trop $\mathrm{J}$ Pharm Res 2017; 16: 2953-2958.

8. K Ma, MD Du, MD Liao, SH Chen, GQ Yin, QF Liu. Evaluation of Wound Healing Effect of Punica granatum $L$ Peel Extract on Deep Second-Degree Burns in Rats. Trop J Pharm Res 2015; 14: 73-78.

9. European Commission [homepage on the internet]. Directive 2010/63/EU on the protection of animals used for scientific purposes [cited 2013 Jan 16]. Available from:

http://ec.europa.eu/environment/chemicals/lab_animals/l egislation_en.htm.

10. Chen $Q$, Zhou W, Pu D, Li Z. The inhibitory effect of 15-rIxa4 on experimental endometriosis. Eur $J$ Obstet Gynecol Reprod Biol 2009; 145: 200-204.

11. Garai J, Molnar V, Varga T. Endometriosis: Harmful survival of an ectopic tissue. Front Biosci 2006; 11: 595 619.
12. Zhou ZH, Weng Q, Zhou JH, Zhou J. Extracts of Salvia miltiorrhiza Bunge on the cytokines of rat endometriosis models. Afr J Tradit Complement Altern Med. 2012; 9(3): 303-314.

13. Li W, Li ZW, Han JP, Li XX, Gao J. Determination and pharmacokinetics of danshensu in rat plasma after oral administration of danshen extract using liquid chromatography/tandem mass spectrometry. Eur J Drug Metab Pharmacokinet 2008; 33: 9-16.

14. Liu $\mathrm{H}$, Lang JH. Is abnormal eutopic endometrium the cause of endometriosis? The role of eutopic endometrium in pathogenesis of endometriosis. Med Sci Monit 2011; 17: 92-99.

15. Liu $T$, Jin $H$, Sun $Q R, X u J H$. The neuroprotective effects of tanshinone IIA on beta-amyloid-induced toxicity in rat cortical neurons. Neuropharmacol 2010; 59: 595-604.

16. Matkowski A, Zielinska S, Oszmianski J. Antioxidant activity of extracts from leaves and roots of Salvia miltiorrhiza Bunge, S. przewalskii Maxim., and S. verticillata L. Bioresour Technol 2008; 99: 7892-7896.

17. Sternlicht MD, Werb Z. How matrix metalloproteinases regulate cell behavior. Annu Rev Cell Dev Biol 2001; 17: 463-516.

18. Zhou HE, Nothnick WB. The relevancy of the matrix metalloproteinase system to the pathophysiology of endometriosis. Front Biosci 2005; 10: 569-575.

19. Styer AK, ullivan BT, Puder M, Arsenault D. Ablation of leptin signaling disrupts the establishment, development, and maintenance of endometriosis-like lesions in a murine model. Endocrinol 2008; 149: 506514.

20. Chung HW, Lee JY, Moon HS. Matrix metalloproteinase2, membranous type 1 matrix metalloproteinase, and tissue inhibitor of metalloproteinase-2 expression in ectopic and eutopic endometrium. Fertil Steril 2002; 78: 787-795.

21. Huang HF, Hong LH, Tan Y. Matrix metalloproteinase 2 is associated with changes in steroid hormones in the sera and peritoneal fluid of patients with endometriosis. Fertil Steril 2004; 81: 1235-1239.

22. Zong WX, Edelstein LC, Chen C. The prosurvival bcl-2 homolog bfl-1/a1 is a direct transcriptional target of nfkappab that blocks tnfalpha-induced apoptosis. Genes Dev 1999; 13: 382-387. 